\title{
BIOETHICAL DEBATE REGARDING GYMS' NEED FOR MEDICAL CERTIFICATES FOR AMATEUR SPORTSMEN
}

\begin{abstract}
Dario Palhares ${ }^{1}$, Flávia Squinca ${ }^{2}$, Antônio Carlos Rodrigues ${ }^{3}$
Abstract: Sports Medicine comprises two branches: one, related to professional athletes and the other, related to the general population vis a vis sports and physical activity. The bioethical conflicts involving professional athletes are different from those of amateur practitioners. There is a constant deliberation related to the requirement of medical evaluation before admission to a gym. There are regional laws that make the medical certificate an obligatory document. It is observed that in the creation of these laws, the arguments are guided by a way to transfer responsibility from the gym to the physician who has attended the client. In a sense, the laws that indiscriminately require medical certificates subvert the ethics of the medical practice because the medical officer is not capable to assure that a given patient has no medical issue; instead the medical work is to try to identify the cause to a complaint. The gyms provide clients with orientation and supervision by providing them with qualified professionals. Although the need for medical certificates for everybody is unethical, a detailed medical evaluation is needed for gym clients who may present clinical manifestations during exercise or have some specific clinical conditions.
\end{abstract}

Key words: sports medicine, ethics, medical certificate

Debate bioético respecto de la necesidad de los gimnasios de contar con certificados médicos para deportistas amateur

Resumen: La medicina deportiva abarca dos ramas: una relacionada con atletas profesionales y la otra con la población general, vis a vis deportes y actividad física. Los conflictos en bioética con atletas profesionales son diferentes de los que tienen los practicantes amateur. Existe un debate relacionado con el requisito de evaluación médica antes de ser admitido a un gimnasio. Hay leyes regionales que exigen presentar un certificado médico. Se observa que, en la creación de estas leyes, los argumentos se guían por una forma de transferir responsabilidad desde al gimnasio al médico que atiende al cliente. En cierto modo, las leyes que indiscriminadamente exigen certificados médicos socavan la ética de la práctica médica, porque el médico oficial no es capaz de garantizar que un paciente dado no tiene un problema médico; en vez de ello el trabajo médico consiste en tratar de identificar la causa de una demanda. Los gimnasios proporcionan a los clientes orientación y supervisión mediante profesionales cualificados. Aunque la necesidad de certificados médicos para todos no es ética, se necesita una evaluación médica detallada para clientes de gimnasio que puedan presentar manifestaciones clínicas durante el ejercicio o que tengan alguna condición clínica específica.

Palabras clave: medicina deportiva, ética, certificado médico

Debate bioético sobre a necessidade de atestados médicos para os desportistas amadores em ginásios

Resumo: Medicina Desportiva compreende dois ramos: um, relacionado com os atletas profissionais e outro, relacionado com a populaçáo em geral, vis a vis esportes e atividade física. Os conflitos bioéticos envolvendo atletas profissionais são diferentes daqueles de praticantes amadores. Há uma deliberação constante relacionada com a exigência de avaliação médica antes da admissão para um ginásio. Existem leis regionais que fazem do atestado médico um documento obrigatório. Observa-se que na criação dessas leis, os argumentos são guiados pela intenção de transferir a responsabilidade do ginásio para o médico que atendeu o cliente. Em certo sentido, as leis que exigem indiscriminadamente atestados médicos subvertem a ética da prática médica porque o médico náo é capaz de assegurar que um determinado paciente não tem nenhum problema médico; ao contrário, o trabalho médico é tentar identificar a causa de uma denúncia. Os ginásios fornecem aos clientes orientação e supervisão, proporcionando-lhes profissionais qualificados. Embora a necessidade de atestados médicos para todos não é ética, é necessária uma avaliação médica detalhada para os clientes do "gym” que podem apresentar manifestaçóes clínicas durante o exercício ou têm algumas condiçóes clínicas específicas.

Palavras-chave: medicina desportiva, ética, atestado médico

\footnotetext{
${ }^{1}$ Cátedra Unesco da Universidade de Brasília, Brasil

Correspondência: dariompm@unb.br

${ }^{2}$ Universidade de Brasília, Brasil

${ }^{3}$ Programa de Pós-Graduação em Bioética da Cátedra Unesco da Universidade de Brasília, Brasil
} 


\section{Introduction}

According to the Fédération Internationale de Médecine Sportive (FIMS)(1), Sports Medicine acts over two major strands: the medicine of the professional athlete and the medicine of sports and physical activity in general. The medical sport societies in general consider that physical exercise, when well conducted, is a way of health promotion, improving practically all organic aspects, being indicated to all the people since childhood(2).

However, excess exercise can lead to repetitive strain injury. According to Melo(3) sports and physical activities may be healthy practices for the general population, but the same cannot be said for the professional athlete: the image of the athlete as an example of health, of self improvement is not in accordance with the spate of lesions suffered throughout their careers, which are not seen by the people as injuries caused due to repetitive strain related to professional diseases, but merely as accidents. Thus, the bioethical conflicts involving professional athletes are not the same as those of the general population. The bioethical concerns regarding professional athletes can be initially consulted in Holm et al.(4) and Assumpção et al.(5).

Regarding amateur sportsmen, there is still some debate about the necessity of medical evaluation prior to their engagement in gyms. In Brazil, according to Doin(6), there is no federal law to regulate this, but there are regional initiatives (states and towns) that approach this topic.

In the State of Rio de Janeiro, the Law 2.014 of the year 1992 says in 10 article that "it is obligated the presentation of a medical certificate of physical fitness in the engagement in gyms and martial arts classes, bodybuilding and gymnastics of any type, which must be renewed every 12 months, archived and registered in the file of the client or pupil."

In the city of Curitiba, the Municipal Law 13.559 of 2010 orders that "the gyms or similar places and the promoting entities of events related to sports must require, at the moment of inscription or engagement, the presentation of a medical certificate of physical fitness. This document must be renewed every 12 months in case of continuous sports practice".
In the city of Sáo Paulo, there was a legal debate: the Ordinary Law 15.527 of 2012 made it mandatory for gyms to obtain medical certificates every 6 months, but this document was partially repealed by the Law 15.681 of 2013 that determined the need "for physical activity practices and amateur sports, the answer to the Physical Activity Readiness Questionnaire (PAR-Q) as described in the Annex I of this law, renewed annually.

$\int 4^{0}$ In the hypothesis of (...) positive responses to any of the questions of PAR-Q it will be needed the assignment of the Term of Responsibility to Physical Activity Practice according the Annex II of this law.

$\int 5^{\circ}$ The response to $P A R-Q$ will be required to the amateur sports practitioners of between 15 and 60 years, so that all the others must present a medical certificate in the terms of the $\$ 10^{\circ}$.

The Municipal Law of São Paulo seemed to have the cooperation of experts in the field of Sports Medicine, but since it determined the adoption of PAR-Q, legally it could not develop more accurate instruments. If scientific evolution creates new methods, it will be necessary to change the Law.

It is necessary to question the paradigms and values that motivate an elaboration of these laws. Why is it necessary to medicalize the gym? What epidemiologic facts justify this order? Why must the medical certificate be renewed yearly? What are the bioethical conflicts involved?

\section{The debate around the laws}

Sports Medicine is focused on the health specific problems of professional athletes. Thus we can say that it is a specialty of Labor Medicine(7). According to Melo(3), the athlete undertakes a daily rigor so as to sell the image of being almost superhuman. Even the most talented athlete does not work alone; he cannot exist without a collective event, such as a championship, etc. There are many people involved in the success of the athlete. They include owners of the production means and of asset generated with the work of athletes and the organizers of the sports events and media, which broadcasts the event. The sports event is only the beginning. After this the media conti- 
nues to relay the latest news about the games, the results, the new athletes, etc., thereby acting as advertisement of many economic sectors such as the industry of sports material, of cosmetics or any other industry that associates its products with the image of the athlete(8).

Regarding the health injuries that interfere with the career and the productivity of the athletes, the injuries to the locomotor system (bones, ligaments, cartilages, joints) are the most prevalent and the major preoccupation of Sports Medicine in prevention, early diagnosis and treatment $(2,4)$. But the most important risk to life is the presence of heart diseases such as malformations, rheumatic injuries, etc., but these are of low prevalence(9). The heart diseases can be silent and asymptomatic until the chronic stressful condition of training and competition enhances the chances of arrhythmias and sudden death. Luckily, the sudden death of an athlete is very uncommon, with just a small epidemiologic impact(9). Ghorayeb et al.(10) estimate that around 30 sudden deaths of athletes occur yearly, a number much lower to that of athletes who die in car accidents(11). The economic dynamics of the work of athletes explains why such uncommon events have become an issue: because the death of an athlete can ruin a complex structure of selling images and products: is this the super-human who died suddenly, 'from nothing', exhausted in the championship?

Nowadays, the professional athletes are being examined with the aim of early diagnosis of heart diseases. The Sports Medicine societies worldwide have not reached a consensus on the necessity of complementary medical tests prior to the participation in competitions. Sofi et al.(9) believe that a resting electrocardiogram is enough, while Ghorayeb et al.(10) say that several other tests may be needed, especially for those athletes who present signs of heart diseases. One bioethical question regarding these protocols is that no clinical or complementary exams are accurate enough to detect diseases. Ghorayeb et al.(10) and Palhares \& Santos(7) state that a complementary exam is destined to detail the semiological study of a patient who presents some clinical manifestations. Wait that a group of exams prove that a given person 'has nothing' is an inversion of the ethical and scientific proposal when carrying out com- plementary exams. It is noteworthy that although the investment in complex machineries to diagnose diseases with small prevalence can be too expensive, they can aggregate value to the sports business, as in the long term they will be economically viable.

So, the particularities of the professional athletes end up being transferred to the business of the amateur practitioners. In Curitiba, the assemblyman who proposed the law "informed that (...) many people search for gyms (...), however, many people are unaware of their health condition and consequently are not able to support the series of exercises they will be submitted to (...). The most effective way to identify the carriers of silent cardiovascular diseases is the periodic medical evaluation"(12).

In Rio de Janeiro, the arguments are similar(13): "physical activities have proven to give benefits to health (...). The evaluation and the diagnosis of the so-called safety means of physical activities are carried out by the medical exam, which contains (...) a general evaluation of health, including, among other exams, an electrocardiogram for a cardiovascular evaluation (...) that must obey to the same periodicity of check-ups, indicated by doctors every 6 months".

In São Paulo, the Law 15.681/2013, which has reduced the demand for medical certificates, was guided by the argument that(14) "the necessity of carrying out exams every 6 months was excessive and was bringing unnecessary charges to the gyms. The National Agency of Health Surveillance (Anvisa) classifies the activities as of low risk. The law pleased the gym businessmen. The president of the syndicate of gyms of Sao Paulo (...) affirms that the questionnaire can be more important because it serves as a basis for a physical education professional to carry out tests and determine the intensity of the exercises that a practitioner can do. To Bertevello, the simple realization of medical exams can not guarantee that there will be no health problems during the exercises".

Besides the debate involving the elaboration of the laws, Doin(6) stated that the gyms have objective responsibility, i.e. they are responsible for injuries during the practice of physical exercises, except when the client acts with negligence, or 
in fortuitous situations. "In this sense, the medical certificate guaranteeing that the client was able to do physical exercise and that his injury or death was no one's fault brings more safety to the company. (...) The medical certificate has two great functions: the first is the simple obedience to the legal norms (...). The second (...) relies on the prevention of accidents with the clients, as the submission to a medical exam can prevent a hidden disease, as well as a protection of the company in case of the occurrence of an injury related to health. It is associated with the civil responsibility of the gyms regarding their obligation of taking care of their clients and the absence of responsibility in case of a sinister event".

\section{Bioethical approach and analysis of speech}

Regarding public health policies, the epidemiological knowledge and studies about the effectiveness and costs of a given policy are very important. From the analysis put forward in this study it is evident that the arguments are not guided by an epidemiological problem and even less by the effectiveness of the requirement of medical certificates. On the contrary, according to Battistella et al.(15), the incidence of lesions in newcomers is more in the first three months of the practice, that is, there is no need for semestral or annual exams. It is a paradox that Law 13.559 required the renewal of the medical certificate at regular intervals to the gym: if the practice is continued, what is the requirement of a new medical evaluation? Is it feasible that a doctor will cancel a physical activity about which a person feels good and well adapted?

Clearly, the arguments recognize the benefits of regular physical activity and that there are some risks inherent to them. However, the arguments in favor of these laws present gaps of fundaments. The risk of a person in suffering a cardiovascular accident as a consequence of going to a gym does not present epidemiological repercussion, but exactly the other way around: the regularity of frequenting the gym should be stimulated as prophylaxis against cardiac events.

There is no precedence of a medical practitioner telling a given person that he has 'nothing'. Medicine tries to identify the cause of a given complaint. Bertevello(14) is right in saying that neither the physical examination nor any of the complementary exams present complete accuracy in saying who is sick and who is not. Each medical test generates semiological data that by definition is probabilistic. The electrocardiogram, as cited in the proposal of Rio de Janeiro, is not capable of showing the diagnosis of every cardiac condition, and inversely an altered exam does not necessarily mean disease. Statistics(16) shows that the more uncommon a given disease is, the most difficult it is to recognize or prevent it. Since sudden death during sports is a rare event, it is highly probable that the susceptible patients will be not diagnosed, that is, the investment in a medical exam may not bring the prevention desired, when the whole population is taken into consideration.

The speech of lawyer Doin(6) highlights the interests that the gyms might have in requiring a medical exam: the transference of responsibility. In the face of misfortune, the gym can brandish the medical certificate in such a way that in an eventual lawsuit, the blame would fall on someone else. But what responsibility does a gym have? What previous guilt would present a gym facing an episode of sudden death of a client?

Biologically, the locomotor system is under the domain of the wills of the cerebral cortex. Any person can run in a park, buy gym equipment for his home, swim in a river, a waterfall, or in the sea without needing a medical certificate. There are many playgrounds where children can play for free. Thus we can say that if physical activity is inherent to human beings, why should we need a certificate to go exercising in a gym? What does a gym have that is so different and threatening?

A gym is a place that brings together people with the same objective. It is the same focus that guides professionals in Physical Education who supervise the clients. Some gyms rent the space along with the equipment. Many residential buildings offer gym spaces with diverse machines. So, instead of doing exercise outside, clients can come into the gyms which offer supervision and orientation. This way, the objective responsibility of a gym must fall on the qualified professionals who know how to guide the clients and to recognize abnormal signs that indicate the need for a detailed clinical evaluation. While a medical cer- 
tificate comes from a short interaction between the doctor and the practitioner, the physical education trainer will follow the client over time and will be the first to see complications that might occur. The medical certificate can never mean the transfer of the responsibility that the gyms have in hiring trained professionals able for first aid.

The laws that require medical certificates indiscriminately subvert the ethics of medical practice. Medicine has never been involved in the selection or exclusion of participants of a gym. Medicine establishes an unwritten contract between a doctor and patient in which the patient, accepts or declines the interventions proposed by the professional(17). Trust is the basis of the relationship that starts with a declaration of the patient - anamnesis. This means that a person who does not want to go to a doctor or is forced to go due to circumstantial obligation can, according to Palhares \& Cunha(18), omit important information about himself and may not even follow some of the medical recommendations. The requirement of a medical certificate also impacts the autonomy of the person(19), who has the right to feel good about himself and capable of carrying out physical activities that are possible outside, in free public places.

Recently, the ethical question about the requirement of medical certificates to amateur practitioners were published in the Code of Ethics of the Faculty of Sport and Exercise Medicine(20), which explicitly publishes in its item 9: "Fitness to practice a Sport - Except when there are symptoms or a significant family medical history, the practice of sport for all should not require a fitness test to be undertaken (...)" This way, this international ethic document is in contrast to the practice that has been created in some Brazilian cities. The Law 15.681 of Sao Paulo was the one closest to this document, but it still kept, without any clinical and epidemiological foundation, the requirement for medical certificate for children. Is it possible that in the future, medical certificates will be needed for children who go to playgrounds?

It must be highlighted that what is unethical is the indiscriminate requirement of a medical certificate, for all. But a more detailed medical evaluation can and must be asked for from gym clients who may present clinical manifestations at the gym, such as fainting, seizures, fall in blood pressure, signs of bulimia, etc.

\section{Conclusions}

Sports Medicine works with two types of people each of which have different epidemiologic profiles concerning exercise: the professional athletes and the amateur practitioners. Each of these categories presents bioethical peculiarities. Regarding physical activity of the general population, gyms must keep adequately qualified staff for supervision of physical exercise. Clients should receive adequate information about general health care that include regular exercise, balanced nutrition, hygiene of body, sleep and mind and signs and symptoms of diseases. The sports medical doctor should offer support and orientation to the practitioners with an increased cardiac risk, while respecting autonomy, freedom and privacy of the person. A medical certificate must never be required as simply one more document to engage to a gym and cannot be used for transfer of responsibilities in a court of law.

\section{Acknowledgements:}

We thank the Indian company Content Concepts for English review and corrections. 
Bioethical debate regarding gyms' need for medical certificates for amateur sportsmen - Darío Palhares et al.

\section{References}

1. Fédération Internationale du Médecine Sportive. Code of ethics. Available at http://www.fims.org/about/code-ethics/ Access in May/2016.

2. Brazilian Society of Sports Medicine. Atividade Física e Saúde. Projeto Diretrizes. Brasília: Conselho Federal de Medicina e Associaçấo Médica Brasileira; 2001.

3. Melo VA. Um produto chamado esporte. Ciência Hoje 2008; 42(250): 10-14.

4. Holm S, McNamee M, Pigozzi F. Ethical practice and sports physician protection: a proposal. British Journal of Sports Medicine 2011; 45(15): 1170-1173.

5. Assumpção L, Sampaio T, Caetano J, Caetano Júnior M, Silva J. Temas e questôes fundamentais na sociologia do esporte. Revista Brasileira de Ciência e Movimento 2010; 18(2): 92-99.

6. Doin J. Atestado médico para os alunos das academias. Available in http://www.gestaofitness.com.br/atestado-medicopara-os-alunos-das-academias Access in February/2014.

7. Palhares D, Santos IL. Bioethical conflicts in occupational medicine: the pre-employment exams. Indian Journal of Medical Ethics 2012; 9(4): 266-268.

8. Melo LM. O poder econômico do esporte. Ciência Hoje 2014; 52(311):18-23.

9. Sofi F, Capalbo A, Pucci N, Giuliattini J, Condino F, Alessandri F, Abbate R, Gensini, GF, Califano S. Avaliação cardiovascular com inclusáo de eletrocardiogramas em repouso e em exercício antes da participação em esportes competitivos: estudo transversal. BMJ Brasil 2008; 1(6): 349-362.

10. Ghorayeb N, Cruz F, Dioguardi G. Sudden death of athletes - a new fact? Arquivos Brasileiros de Cardiologia 2007; 89(6): e169-e170.

11. Wikipedia. List of sportspeople who died during their careers. Available in http://en.wikipedia.org/wiki/List_of_sportspeople_who_died_during_their_careers Access in February/2014.

12. Vereador Zé Maria. Atestado médico em academias. Available in http://www.cmc.pr.gov.br/anexo.php?anexo=2004 Access in February/2014.

13. Vidor G. 2005. Ementa: modifica a Lei 2014/92. Available http://alerjln1.alerj.rj.gov.br/scpro0307.nsf/1061f759d9 7a6b24832566ec0018d832/e029d4913cbb5835832570bc005abe68?OpenDocument\&CollapseView. Access in March/2014.

14. Lei desobriga academias de exigir exames médicos em SP. Globo (newspaper) 10/01/2013. Available in http://g1.globo. com/sao-paulo/noticia/2013/01/lei-desobriga-academias-de-exigir-exames-medicos-em-sp.html. Access in Febru$\operatorname{ary} / 2014$.

15. Battistella LR, Shinzato GT, Kiss HCM, Santomauro AC, Yazbek P. Lesōes osteomioarticulares. Revista do Hospital das Clínicas da Faculdade de Medicina de São Paulo. 1993; 48: 156-160.

16. Motulsky H. Intuitive Biostatistics. Oxford: Oxford University Press; 1995.

17. Marchi MM, Sztajn R. Autonomia e heteronomia na relação entre profissional de saúde e usuário dos serviços de saúde. Revista Bioética 1998; 6(1): 39-46.

18. Palhares D, Cunha ACR. Ethical approach to aggressive situations involving depedent patients and doctors. Revista Latinoamericana de Bioética 2013;13(1): 74-79.

19. Wanssa MCD. Autonomy versus beneficence. Revista Bioética 2011; 19(1): 105-117.

20. Faculty of Sport and Exercise Medicine. FSEM Professional Code. United Kingdom: 2011.

Received: May 3, 2014

Accepted: December 29, 2014 